\title{
重篤な副作用発生要因の分析と予防対策の検討
}

\author{
宮地典子*1，奥隅貴久美*2，古川広志*2，佐竹尚子*2，片平洌彦*3
}

\section{Preventive Measures against Adverse Drug Reactions on the Basis of Case Analyses of Monitored Serious Adverse Events}

\author{
Noriko MIYACHI*1, Kikumi OKUZUMI*2, Hiroshi HURUKAWA*2, Syoko SATAKE*2, \\ Kiyohiko KATAHIRA*3 \\ *1 Nishikicho Pharmacy \\ 1-17-15 Nishikicho, Tachikawa 190-0022, Japan \\ *2 Tachikawasogo Hospital \\ *3 Department of Clinical Pharmacology, Division of Information Medicine Medical Research \\ Institute, Tokyo Medical and Dental University
}

\begin{abstract}
$\langle$ Abstract〉
Objective : To analyze serious adverse drug reactions (ADRs) in terms of their occurrence, the related factors and the necessary means to avoid such ADRs, and proposal of possible preventive measures against ADRs.
\end{abstract}

Design : Case series.

Methods : Out of 598 cases collected through an in-patient drug monitoring conducted from April 1990 to March 1996 in Hospital T, 59 cases which were of Grade 3 of the Ministry of Health and Welfare Standards for Severity Classification of ADRs were selected for this study. By classifying the causes of and the possibilities to avoid reactions in 59 cases, we discussed measures to prevent serious reactions to drugs.

Results : Symptoms involved were, in descending order, hypersensitivity, hepatic disorder, blood disorder, renal failure, cadiovascular system disorder, and other symptoms. Causal drugs were, in descending order, antibiotics, central nervous system drugs, circulatory drugs, gastrointestinal drugs, and other drugs.

Regarding the causes for the ADRs, factors involved in "usage", such as indication and dosage, represented the highest rate, $40.7 \%$. In a detailed survey of the possible avoidance of such reactions, $49.2 \%$ of serious ADRs were judged preventable by careful administration of the drugs. Further, $15.3 \%$ of the cases were thought to have resulted from a lack of or an inadequate description in the package insert.

Conclusions : The study indicates that the following steps are necessary to prevent ADRs. : (1) To be appropriately cautious to indications and dosages of the drug (including, in particular, indications and dosages for the aged, and renal failure or allergic patients, and the adjustment of dosage on the basis of drug-drug interaction) ; (2) To adhere strictly to contraindication ; (3) To offer suitable information on the ADRs to the patient who has experienced such a reaction ; and, (4) To be aware of unusual conditions by careful follow-up at an early stage after the administration.

The following action plans were considered important for carrying out the steps mentioned above :

*1 錦町薬局 ₹ 190-0022 立川市錦町 1-17-15

*2 立川相互病院 $\quad * 3$ 東京医科歯科大学難治疾患研究所情報医学研究部門 (臨床薬理学) 
40 原 著

1) to deepen medical workers awareness to prevent ADRs ;2) to establish a system that can correctly offer fundamental and essential information to physicians ; 3) to standardize drug treatment according to patient condition (age, renal-failure, etc.) and to establish a safety assurance system.

Key words : serious adverse drug reaction, in-patient drug monitoring, preventive method of adverse drug reaction, package insert, drug information

\section{緒 論}

副作用モニター制度 ${ }^{1)}$ の目的は市販後に発生す る副作用を早期発見し迅速な対応と伝達を行い, 医薬品の安全性を確保することにある。

わが国における副作用モニター報告数 ${ }^{2}$ は実数 をはるかに下回る3状況であり，いまだ十分に機 能しているとは言いがたい1). 薬害 HIV，そして ソリブジン事件と近年なおも発生する薬害被害の 代償のもとに, 1997 年 7 月より厚生省薬務局の一 部は医薬安全局と改組され, 副作用モニター制度 も「医薬品等安全性情報報告制度」と名称を改め, 従来のモニター施設中心から, 全医療機関の医師, 薬剤師からの個人の判断に基づく報告を促すシス テム出に変えられた。

このシステムが生かされるためには病院内での 副作用モニターに対する関心を高め，自発報告に 伴う法的リスクの考え方 ${ }^{4} や ，$ 情報をいかに診療 現場で有効に活用するかなどの検討を深め, 積極 的な協力を促す組織的対処が重要であると考え る。

立川相互病院（以下T病院）では安全な薬物治 療を実践する上での病院内の副作用モニターの意 義を重視し，1980 年より病院内のシステム化を 図った (図 1). 病院内副作用モニターシステムの 詳細は第 1 回日本薬剤疫学研究会シンポジウムに て報告した ${ }^{5)}$.

我々は副作用モニター事例を検討するなかで, より注意深い薬物治療により避けられたと判断さ れる事例が多いことから, 副作用の発生要因を調 查する必要性を認めた。そこで, 1990 年 4 月より 1996 年 3 月までの 6 年間の入院患者においてモ ニターされ，因果関係の検討を経た重篤例に関し て副作用発生要因を分析し, 副作用予防の可能性 と予防対策の検討を行った。

\section{方 法}

\section{1．副作用症例の検出と評価}

副作用症例の検出は主として以下の方法により 行う. (1) 医師, 看護婦から薬剤師に対し, 副作用 が疑われる症例の調查依頼などを通じた検出，(2) 薬剤師による処方チェック, 服薬指導などを通じ た検出，(3) 採用申請薬の院内試用評価を通じた検 出.

検出した副作用は報告用紙に記録し，症例の詳 細な経過, 文献的検討を加えて因果関係を評価し, 薬事委員会にて審議を行う.

時間的経過が矛盾しないことを前提に，以下の 基準に基づいて症状と薬剤との因果関係を評価す る.「確実」：確定試験（皮膚試験, リンパ球刺激 試験，チャレンジテストなど）陽性，再投与にて 同様に症状が出現，あるいは投与直後の特異反応 のいずれかに該当する。「ほぼ確実」：使用薬剤に おいて既知の副作用症状である。「可能性が高 い」：中止により回復, 他の要因が考えられない. 「不明」：疑われるが上記の証拠がない.

\section{2. 調査対象および調査項目}

T病院 (345 床) の入院患者について収集した副 作用症例のうち 1990 年 4 月～1996 年 3 月の期間 の症例 598 件のうち, 厚生省の医薬品副作用重篤 度分類基準によりグレード 3 に分類される重篤例 59 件（因果関係不明の 7 件を除く）に関して, (1) 発生実態（副作用症状，原因薬，投与量 - 投与期 間，性・年齢，転帰)，(2) 副作用発生要因，(3) 副 作用回避の可能性を調査した。

\section{3. 副作用発生要因と副作用回避の可能性に関する 分類基準}

副作用発生要因は, 不適切な適応・投与量・投 与方法, 使用開始後の観察不十分による副作用を 「薬剤の不適切な使用および観察不十分」, アレル 


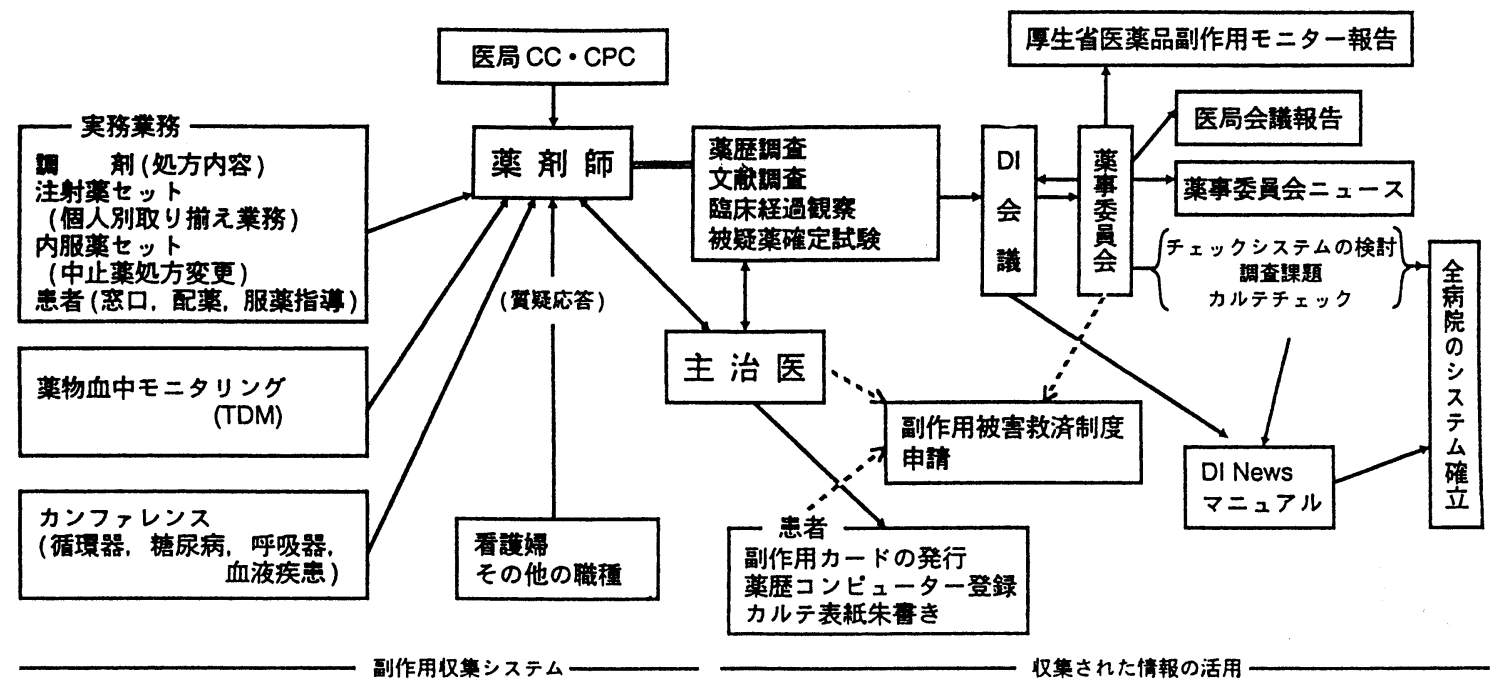

図 1 院内副作用モニターシステムと情報の活用

ギー性など予知できない副作用を「患者の体質等 の要因」, 国内報告がありながら医療用医薬品添 付文書（以下添付文書と略す）に未記載であった り，重篤性を示す記載がない副作用を「添付文書 の記載不備」,過去に同じ薬剤で同様の副作用の既 往がありながら，患者に指導していなかった，あ るいは指導の不足により患者が誤用したことによ る副作用を「患者への情報伝達の不備」に分類し た。

副作用回避の可能性に関しては, 回避が困難な 副作用として, 国内報告がなく添付文書に未記載 な副作用を「未知であり予測困難」, アレルギー性 など予知できない副作用を「既知であるがやむを えない」とした，回避可能な副作用として，国内 報告がありながら添付文書に未記載であったり， 重篤性を示す記載がない副作用を「添付文書の記 載不備」とし, 添付文書の改善により回避可能と 判断した. 臨床現場での回避が可能であると判断 した副作用として，過去に同じ薬剤で同様の副作 用の既往がありながら患者に情報が伝達されてい なかった, あるいは指導の不足のための誤用によ り副作用を「患者への情報伝達の不備」, 不適切な 適応, 投与量, 使用方法などによる副作用を「既 知であり現場での注意不足」に分類した。

\section{結 果}

\section{1. 症状と薬剤の因果関係の評価}

「確実」と判断した例は 17 件であり，その根拠 は確定試験陽性による例が 5 件，再投与にて同様 の症状が出現した例が 5 件, 投与直後の特異反応 による例が 7 件であった。「ほぼ確実」と判断した 例は 6 件，「可能性が高い」と判断した例は 36 件 であった. 以下，これらの計 59 件について記す。

\section{2. 副作用発生実態}

1) 副作用症状

厚生省の医薬品副作用重篤度分類基準に準じて 分類した結果，過敏症状が 13 件 (22.0\%)，肝障 害 9 件 (15.3\%), 血液障害 9 件 (15.3\%), 腎障 害 7 件 $(11.9 \%)$, 循環器系障害 5 件 $(8.5 \%)$, 呼 吸器系障害 5 件 $(8.5 \%)$, 精神神経系障害 3 件 (5.1\%), 電解質異常 3 件 $(5.1 \%)$ ，その他 1 件 (1.7\%) であった.

過敏症状の発生が最も多かったが，そのうち， アレルギー体質の患者での発生が 4 件, 副作用既 往歴ありの患者での発生が 2 件であった。

\section{2 ）原因薬}

多い順に，抗生物質 13 件 (22.0\%)，中枢神経 系用薬 10 件 (16.9\%), 循環器用薬 9 件 $(15.3 \%)$, 
代謝性医薬品 8 件 (13.6\%), 消化器官系用薬 5 件 (8.5\%), 腫瘍用薬 5 件 $(8.5 \%)$ ，アレルギー用薬 2 件 $(3.4 \%)$, 漢方薬 2 件 $(3.4 \%)$ ，その他 5 件 (8.5\%) であった.

\section{3 ) 投与期間}

1 回の投与により発生した例が 16 件 (27.1\%) であった。そのうち 10 件は過敏反応による症状で あった. 2 回以上，1〜10日の投与による発生が 16 件 $(27.1 \%) ， 11 \sim 30$ 日の投与による発生が 13 件 (22.0\%) であり，76.2\%が 30 日以内の投与に よる発生であった. 31〜 60日の投与による発生は 7 件 (11.9\%)，61～90 日の投与による例は 3 件 $(5.1 \%), 91$ 日以上の投与による例は 4 件 $(6.8 \%)$ であった。

\section{$4 ）$ 性・年齢}

性別では男性27件 (45.8\%)，女性32件（54.2 \%) であった。年代別では 0 〜 歳が 1 件 (1.7\%)，10〜19 歳, 20〜29 歳が各 2 件 (3.4\%), $30 \sim 39$ 歳が 3 件 (5.1\%)，40 49 歳が 4 件 (6.8\%)，50〜 59 歳が 9 件 (15.3\%)，60 69 歳が 13 件 (22.0\%), 70〜79 歳が 16 件 (27.1\%), 80〜89 歳が 9 件（15.3\%）であった。

\section{5 ) 転帰}

回復が 50 件 $(84.7 \%)$, 副作用報告の時点での 軽快が 6 件 (10.2\%), 未回復 3 件 (5.1\%) であっ た. 未回復例は原疾患による全身状態が悪く, 副 作用症状の回復をみないまま死亡に至った例も含 む.

\section{3. 副作用発生要因}

副作用の発生要因を分析した結果を表 1 に示す。

「薬剤の不適切な使用および観察不十分」と判断 されるものが 24 件 $(40.7 \%)$,「患者の体質等の要 因」が 21 件 (35.6\%), 「添付文書の記載不備」が 9 件 $(15.3 \%)$,「患者への情報伝達の不備」が 5 件 (8.5\%) であった.

「薬剤の不適切な使用および観察不十分」に分類 される内容の内訳は，高齢者・腎機能低下者にお ける過量投与 12 件 ( $50.0 \%)$, 投与初期の検査フォ ローや異常の発見の遅れ 5 件 $(20.8 \%)$, 適応禁忌 の患者への投与 2 件 $(8.3 \%)$, 副作用既往がある 患者への再投与 2 件 $(8.3 \%)$, 不適切な使用法 2
件 (8.3\%)，相互作用 1 件（4.2\%）であった。

\section{4. 副作用回避の可能性}

以上の結果に基づき副作用の回避可能性を分析 した（表 2).

回避が困難であった副作用は「未知であり予測 困難」 3 件 (5.1\%)，「既知であるがやむをえない」 18 件 (30.5\%) であり, 計 21 件 (35.6\%) であっ た。

「未知であり予測困難」と判断した症例は, erythromycinによる間質性腎炎, 市販の葛根湯 （カコナールK）によるアナフィラキシーショッ ク, cyanamide による TEN 型薬疹の 3 件であ る、いずれも国内報告がなく, 添付文書の記載が なかった。これら 3 件は発生要因としては「患者 の体質等の要因」に分類した症例である.

「既知であるがやむをえない」は肝障害, 血液障 害, 過敏症状に分類されアレルギー性副作用と判 断した 18 件 (30.5\%) である。

回避可能な副作用は「添付文書の記載不備」9 件 (15.3\%), 「患者への情報伝達の不備」5 件 $(8.5 \%)$ ，「既知であり現場での注意不足」 24 件 (40.7\%)，計 38 件 $(64.4 \%)$ であった。

「添付文書の記載不備」9 件の内訳は, clofibrate による肝腎障害, triazolamによる肝障害のよう に, 発生時点の添付文書には「肝機能検査值の上 昇」という表現のみで重篤性を示す記載がされて いない例, sulindacによる血小板減少症のように 国内報告がありながら未記載であった例, cimetidine による血小板減少症のように腎機能 に応じた厳密な投与量の設定を明記すべき例, そ して amphotericin B (注射用) の初回投与による 全身痙攣発作を発現した事例では, 添付文書の「用 法及び用量」の記載が，より安全な投与方法につ いて, 後段に「副作用の発現のため投与困難な場 合には，初回量は 1 日 $1 \mathrm{mg}$ (力価）から開始し,」 と付記する表現になっている例などである。この ような副作用は添付文書の記載の改善により副作 用の回避につながると判断した。

臨床現場での回避が可能であったと判断した例 は「患者への情報伝達の不備」の 5 件 (8.5\%), 「既知であり現場での注意不足」 24 件 (40.7\%) で 
薬剤疫学 Jpn J Pharmacoepidemiol, 3 (1) May 1998：43

表 1 薬効分類別にみた副作用発生要因

\begin{tabular}{|c|c|c|c|c|c|}
\hline 薬効分類 & $\begin{array}{c}\text { 薬剤の不適切な使用 } \\
\text { およ゙観察不十分 }\end{array}$ & $\begin{array}{c}\text { 患者の体質等の } \\
\text { 要因 }\end{array}$ & $\begin{array}{c}\text { 添付文書の } \\
\text { 記載不備 }\end{array}$ & $\begin{array}{l}\text { 患者への情報 } \\
\text { 伝達の不備 }\end{array}$ & 合 計 \\
\hline 抗生物質 & 6 & 5 & 1 & 1 & 13 \\
\hline 中枢神経系用薬 & 3 & 3 & 2 & 2 & 10 \\
\hline 循環器系用薬 & 6 & 1 & 2 & 0 & 9 \\
\hline 代謝性医薬品 & 4 & 3 & 0 & 1 & 8 \\
\hline 消化器官系用薬 & 0 & 1 & 4 & 0 & 5 \\
\hline 腫瘍用薬 & 3 & 2 & 0 & 0 & 5 \\
\hline 漢方薬 & 0 & 1 & 0 & 1 & 2 \\
\hline アレルギー用薬 & 0 & 2 & 0 & 0 & 2 \\
\hline その他 & 2 & 3 & 0 & 0 & 5 \\
\hline 合計 $(\%)$ & $24(40.7)$ & $21(35.6)$ & $9(15.3)$ & $5(8.5)$ & $59(100)$ \\
\hline
\end{tabular}

表 2 薬効分類別にみた副作用回避の可能性

\begin{tabular}{|c|c|c|c|c|c|c|}
\hline \multirow[b]{2}{*}{ 薬効分類 } & \multicolumn{2}{|c|}{ 回避困難な副作用 } & \multicolumn{3}{|c|}{ 回避可能な副作用 } & \multirow[b]{2}{*}{ 合 計 } \\
\hline & $\begin{array}{c}\text { 未知であり } \\
\text { 予測困難 }\end{array}$ & $\begin{array}{l}\text { 既知であるが } \\
\text { やむをえない }\end{array}$ & $\begin{array}{c}\text { 添付文書の } \\
\text { 記載不備 }\end{array}$ & $\begin{array}{c}\text { 患者への } \\
\text { 情報伝達の不備 }\end{array}$ & $\begin{array}{c}\text { 既知であり現場 } \\
\text { での注意不足 }\end{array}$ & \\
\hline 抗生物質 & 1 & 4 & 1 & 1 & 6 & 13 \\
\hline 中枢神経系用薬 & 0 & 3 & 2 & 2 & 3 & 10 \\
\hline 循環器系用薬 & 0 & 1 & 2 & 0 & 6 & 9 \\
\hline 代謝性医薬品 & 1 & 2 & 0 & 1 & 4 & 8 \\
\hline 消化器官系用薬 & 0 & 1 & 4 & 0 & 0 & 5 \\
\hline 腫瘍用薬 & 0 & 2 & 0 & 0 & 3 & 5 \\
\hline 漢方薬 & 1 & 0 & 0 & 1 & 0 & 2 \\
\hline アレルギー用薬 & 0 & 2 & 0 & 0 & 0 & 2 \\
\hline その他 & 0 & 3 & 0 & 0 & 2 & 5 \\
\hline 合計 $(\%)$ & $3(5.1)$ & $18(30.5)$ & $9(15.3)$ & $5(8.5)$ & $24(40.7)$ & $59(100)$ \\
\hline
\end{tabular}

あり, 計 29 件 (49.2\%) であった.「患者への情 報伝達の不備」の 5 件は, 過去に同一の薬剤によ る副作用既往がありながら，患者自身にその情報 が伝えられていなかったために同一の薬剤が処方 されたり自己判断で服用し, 再び副作用症状を発 現した 3 件（柴胡桂枝乾姜湯による間質性肺炎, minocycline hydrochloride による PIE 症候群, indometacin suppository による喘息発作), 患者 への使用方法の指導が不十分なために患者が過量 に使用して副作用を発症した 2 件 (warfarinによ る上部消化管出血, indometacin suppository
よる低体温, 意識低下, 血圧低下) であった。

「既知であり現場での注意不足」 24 件の内訳は, 過量投与に関連した副作用が 12 件, 投与初期の検 查実施や異常症状のチェックに関係した副作用が 5 件 (肝障害や電解質異常の例での投与初期の検 查值のフォロー, Stevens-Johnson 症候群の例に おける皮膚症状への早期対応)，投与禁忌に関する 副作用が 2 件（腎不全患者への bezafibrate 投与 による横紋筋融解症, 手術前の持続性 $\beta$-blocker の投与による Adams-Stokes 症候群), 副作用既 往歴がありながら再投与した例が 2 例（ビタミン 
$\mathrm{K}_{1}$ によるショック様症状, sulfamethoxazole に よる TEN 型薬疹), 使用方法に関連した副作用が 2 件 (脊椎麻酔時の病攣・呼吸困難, 抗癌剂投与 時の補液量不足による腎不全), および相互作用に 関連した副作用が 1 件 (azathioprine と allopurinol の併用にて, 相互作用を考慮し, azathioprine を $1 / 3 \sim 1 / 4$ に減量すべきところを $1 / 2$ の減量に とどめたことにより汎血球減少症を発症)であっ た。

\section{考 察}

入院患者の副作用発生率に関する報告は米国で 2〜 6.5\% ${ }^{6 \sim 9)}$ と報告されている. T病院で 1990 年 4 月から 1996 年 3 月までの 6 年間に収集し評価 した院内副作用報告は 598 件であり, 同期間の入 院患者数 32,746 名の $1.8 \%$ に相当する. その中で グレード 3 に分類される副作用は 59 件であり,副 作用症例の $9.9 \%$, 全入院患者数の $0.18 \%$ であっ た. 副作用モニターの方法は医師や看護婦から薬 剤師への報告と薬剤師自身による検出によってお り，必ずしも副作用全例がモニターできているわ けではない. なお, 入院治療中の発生のみならず, 他の医療機関での投薬により副作用が発生し，入 院となったケースを含んでいる.

重篤な副作用の回避可能性に関して, The Harvard Medical Practice Study では入院における 副作用の $27.6 \%$ が不注意による ${ }^{8)}$ と結果であ り, Bates DW ら ${ }^{9)}$ 副作用全体では $28 \%$ が，重 篤例では $42 \%$ が予防しうると報告している。

我々の調査では, グレード 3 に分類される副作 用 59 件の分析から,「患者への情報伝達の不備」 5 件, 「既知であり使用上の注意不足 $\rfloor 24$ 件, 計 29 件 $(49.2 \%)$ が医療現場での注意深い薬物治療に より回避可能であると判断され，Bates DW らの 重篤例での予防可能な頻度をやや上回る結果で あった。

添付文書の記載不備に関して，これまでは添付 文書が患者の安全を確保する上で迅速に具体的な 情報を提供するという点で不十分であったといえ る. 厚生省は 1994 年度, 1995 年度の厚生科学研究 として,「医療用医薬品添付文書の見直し等に関す
る研究班」を設置し，現状の添付文書に関する問 題点の整理と, より良い添付文書のあり方につい て検討を行い，その結果に基づいて，1997 年 4 月 25 日付けで, 薬発第 606, 607 号薬務局通知, 薬安 第 59 号薬務局安全課長通知を発出し,「医療用医 薬品添付文書の記載要領」を改正した ${ }^{10)}$.

この改正により，「重要な基本的注意」の項の設 置，「警告」・「禁忌」・「慎重投与」の内容に関する 設定理由の明記，「重大な副作用」に関して副作用 の発現機序，発生までの期間，具体的防止策，処 置方法, 初期症状等が判明している場合の記載な どが義務付けられたことから，具体的で有用な情 報が提供されることが期待される。しかし，さら に最も望まれることは，収集された副作用情報へ の迅速な対応である.評価の確立していない文献, 報告であっても重要な情報は記載すること, 海外 でのみ知られているその他の副作用についても記 載することなどが明記されたことからも，収集さ れた副作用情報への迅速な対処を期待したい.ま た，記載内容の変更が速やかに実施できるよう行 政の指導改善を望みたい.

入院患者における副作用は頻繁に発生してお り，しかも重篤例の多くは予防しうる ${ }^{9)}$ といる。 Bates DW ら ${ }^{9)}$ は予防対策の中心は医師のオー ダーの時点の問題であることを指摘しており, オーダーの誤りの内訳として投与量の誤りが最も 多く，以下，薬剤選択の誤り，アレルギー既往， 投与回数，相互作用と分析している. 我々の調査 結果においても，臨床現場で回避可能であり「使 用上の注意不足」と判断された発生要因の内訳は, 過量投与(高齢者, 腎機能低下時など), 投与初期 の観察, 薬剤の選択, 副作用既往情報の把握, そ して相互作用であり, Bates らの報告に類似した 結果であった.

これらは薬物治療を行ううえで注意すべき基本 的事項である．高齢者や腎機能低下時における薬 剤の選択や投与量に関する情報のように，各薬剤 に関する基本的で重要な情報が医師に把握されて いないといえる。このような実態に関して，副作 用予防に対する認識の欠如9や標準的治療が行わ れていない要ことが指摘されている。また，副作用 
発生の根本的原因として, 薬剤と患者に関する情 報を必要なときに容易に入手するシステムの不備 が指摘されている11).

我々は重篤な副作用を回避する対策として, 副 作用予防に対する医療従事者の意識を高めるこ と, 基本的で重要な情報を医師に確実に伝達でき るシステムを確立すること, 年齢, 腎機能などの 個々の患者の状態に対応できる病院内での薬物治 療の標準とチェックシステムの確立が重要である と考える.そしてこのような対策の確立に薬凨師 がその役割を担わなければならないと考える。

\section{結＼cjkstart論}

T病院院内副作用モニターにより収集した重篤 な副作用の発生要因および副作用回避の可能性を 調査した結果, 重篤な副作用 59 件中 38 件 (64.4\%) は回避可能と判断され，その内訳は，(1) 「添付文書の記載不備」9 件, (2)「患者への情報伝 達の不備」5 件, (3)「既知であり使用上の注意不 足」 24 件であった.これらのうち, (2) (3) は臨床現 場での以下のような注意深い薬物治療により回避 可能と考えられた. (1) 副作用既往情報の把握と患 者への伝達, (2) 適応, 投与量の慎重な決定 (とく に高齢者, 腎機能低下者, アレルギー患者), (3) 投 与初期の検査值フォローによる異常值の早期発 見, 副作用症状への早期対応, (4) 適応禁忌の厳守, (5) 相互作用を考慮した投与量の調節. そして, こ れらの実践を確実に行うためには，

1) 副作用予防に対する医療従事者の意識を高 めること

2 ）基本的で重要な情報を医師に確実に伝達で きるシステムを確立すること

3 ）年齢, 腎機能など個々の患者の状態に対応 できる病院内での薬物治療の標準化と チェックシステム

の確立が重要であると考えられた。

\section{文献}

1）海老原格. 医薬品副作用モニター制度. 診断と治療 $1991 ; \mathbf{5}: 877-82$.

2) 楠正. 薬剤疫学の歴史と現状および今後の課題. 薬剤疫学 $1996 ； 1(1) ： 3-12$.

3）久保田潔. 我が国における PMS の将来へ向けて。 薬剤度学 $1996 ; \mathbf{1}(2): 79-86$.

4）久保田潔, 岡本悦司. 副作用モニ夕一制度改革に期 待する一法的リスクと情報収集・伝達に関する一考 察. 日本医事新報 $1997 ； 3815 ： 73-6$.

5）宮地典子. 副作用モニタリング一薬剤師の立場か ら一. 薬剤疫学 $1996 ; 1(1): 17-8$.

6) Caranasos GJ, Stewart RB, Cluff LE. Drug induced illness leading to hospitalization. JAMA $1974 ; 228: 713-7$.

7) Miller RR. Hospital admissions due to adverse drug reactions. A report the Boston Colaborative Drug Surveillance Program. Arch Intern Med $1974 ; \mathbf{1 3 4}: 219-23$.

8) Brennen TA, Leape LL, Laird N, et al. Incidence of adverse events and negligence in hospitalized patients : results of the Harvard Medical Practice Study I . N Engl J Med 1991; 324:370-6.

9) Bates DW, Cullen DJ, Laird N, et al. Incidence of adverse drug events and potential adverse drug events-Implications for prevention-. JAMA $1995 ; 274: 29-34$.

10）厚生省医薬安全局安全対策研究会監修. 医療用医薬 品添付文書記載要領ガイドブック。薬事日報社, 1997.

11) Leape LL, Bates DW, Cullen DJ, et al. Systems analysis of adverse drug events. JAMA 1995 ; $274: 35-43$.
投 稿受付：1998 年 3 月 20 日 第 2 稿受付: 1998 年 4 月 20 日 掲載決定：1998 年 4 月 27 日 